National Marine

Fisheries Service

Fishery Bulletin

¿s established in 1881 ๙

\section{Costs of at-sea monitoring under government and private contracts in the groundfish fishery of the northeastern United States}

\author{
Abstract-An at-sea monitoring (ASM) \\ program has been a required sup- \\ plement to the Northeast Fisheries \\ Observer Program, National Marine \\ Fisheries Service (NMFS), for monitor- \\ ing catch in the groundfish fishery in \\ the northeastern United States since \\ the inception of comprehensive sector- \\ based management in May 2010. For \\ the initial years of this management \\ program, the NMFS contracted with \\ ASM providers and covered all costs \\ for ASM-related services. Since March \\ 2016 , vessel owners who target ground- \\ fish collectively as groups called sectors \\ have been required to cover the cost of \\ the at-sea component of the ASM pro- \\ Greg Ardini (contact author) \\ Chad Demarest \\ Katherine McArdle \\ Email address for contact author: gregory.ardini@noaa.gov \\ Northeast Fisheries Science Center \\ National Marine Fisheries Service, NOAA \\ 166 Water Street \\ Woods Hole, Massachusetts 02543
} gram through annual contracts with providers. Although subsequent developments have resulted in the NMFS reimbursing sectors for the majority of billed costs, the salient shift has been from government to private negotiation of ASM contracts. We investigated whether private contracting has reduced ASM costs by applying the terms of contracts to trip-level data from the groundfish fishery over the fishing years of 2013-2018. The payment regime of these contracts was compared with average costs per sea day from NMFS-negotiated contracts. We found that private contracts resulted in average cost reductions of $14 \%$ for the at-sea component of the ASM program. Cost reductions may, however, result in other complications, such as reduced observer pay and consequent issues of retention or data quality.

Manuscript submitted 16 December 2019. Manuscript accepted 8 September 2020. Fish. Bull. 118:284-296 (2020). Online publication date: 6 October 2020. doi: 10.7755/FB.118.3.7

The views and opinions expressed or implied in this article are those of the author (or authors) and do not necessarily reflect the position of the National Marine Fisheries Service, NOAA.
Amendment 16 to the fishery management plan (FMP) for the Northeast multispecies fishery, which includes several groundfish species, required implementation of a comprehensive, cooperative catch allocation scheme called sector management. This system of management allows vessel owners to pool allocations of harvest rights and fish them collectively within sectors (Federal Register, 2010). Sectors can be formed by any group of 3 or more individuals who hold limited-access groundfish permits and do not have ownership interests that overlap (Federal Register, 2010). Although amendment 16 did not mandate joining a sector, the majority of vessels active in the groundfish fishery enrolled in 1 of 17 sectors for fishing year (FY) 2010, rather than operate under the alternative management system based on input controls, called the common pool (note that the groundfish fishing year runs from May through April). The sector component of the groundfish fishery has continued to make up the vast majority of effort and catch (Murphy et al. ${ }^{1}$ ).

\footnotetext{
${ }^{1}$ Murphy, T., G. Ardini, M. Vasta, A. Kitts, C. Demarest, J. Walden, and D. Caless. 2018. 2015 final report on the performance of the Northeast multispecies (groundfish) fishery (May 2007-April 2016). NOAA, Natl. Mar. Fish. Serv., Northeast Fish. Sci. Cent. Ref. Doc. 18-13, 128 p. [Available from website.]
}

Amendment 16 stipulated a variety of catch reporting requirements for sectors, including the following: all legalsized fish must be landed, catch must be accurately reported by statistical area, sector-level catch must be reported weekly to the National Marine Fisheries Service (NMFS), and a list of ports where members land their fish must be specified.

Beginning in FY2012, sector participants were also required to fund an at-sea monitoring (ASM) program, designed to collect catch and discard data for sector-enrolled vessels, with the NMFS agreeing to fund the program in the interim (Federal Register, 2010). The transition to industry-funded monitoring, however, did not occur in FY2012 as originally planned, and the federal government continued to fully subsidize monitoring until March 2016.

To implement industry funding of monitoring, sectors that target groundfish were required to have contracts in place with private ASM service providers. These contracts, which have been renegotiated on an annual basis, specify costs for all components of ASM services, including observer time at sea, observer travel, and observer training. Also specified in the contracts are other miscellaneous costs, such as the cost of observer travel in the event 
that a vessel fails to take a trip after its captain had notified an intent to fish. Before a sector vessel embarks on a groundfish trip, the captain must declare an intent to fish through the Pre-trip Notification System (PTNS). Any trip during which species managed under the groundfish FMP will be targeted is eligible to be chosen by the PTNS to have the vessel carry an ASM observer. Trips during which fishermen will target species managed under other FMPs, such as those for the spiny dogfish (Squalus acanthias) or the goosefish (Lophius americanus), may also be eligible, with a few exceptions (Federal Register, 2016; for more information on PTNS trip selection, see Palmer et al. ${ }^{2}$ ).

Under contracts negotiated by sectors, the duties of ASM observers are still defined by the NMFS; these duties have remained consistent since the ASM program was first implemented. Each sector has been required to submit their ASM contract to the NMFS to ensure compliance with applicable sector operation regulations. During FY2016-2018, each of the sectors that actively fished (16 sectors in FY2016-2017 and 14 sectors in FY2018) contracted with 1 of 4 NMFS-approved ASM providers. Within each sector's operations plan, which were reviewed and approved by the NMFS, the sector indicated the intent to actively participate, or not, in the groundfish fishery in the fishing year or years specified in the plan. Sectors that indicated intent to actively fish for groundfish were required to contract with a provider of ASM observers. Those sectors that indicated that they would not be actively fishing for groundfish could operate on a lease-only basis for quota and, therefore, not be required to contract with an ASM provider. In order for a sector to have contracted with an ASM provider, the NMFS must have approved the provider's ability to meet the objectives of the ASM program. During FY2016-2018, 5 providers received approval, and one of those providers did not contract with any sector throughout this period. Three of the 4 providers that contracted with sectors during this period had contracted with the NMFS for ASM coverage prior to March 2016.

Although sectors have been the nominal payer since March 2016, a majority of actual ASM costs have been reimbursed by the NMFS. Rates of reimbursement were $85 \%$ in FY2016 (starting in July) and $85 \%$ in FY2017 (NMFS ${ }^{3,4}$ ). For FY2018, sectors were fully reimbursed for their ASM costs $\left(\mathrm{NMFS}^{4}\right)$. Regardless of cost

\footnotetext{
${ }^{2}$ Palmer, M. C., P. Hersey, H. Marotta, G. R. Shield, and S. B. Cierpich. 2013. The design, implementation and performance of an observer Pre-trip Notification System (PTNS) for the Northeast United States groundfish fishery. NOAA, Natl. Mar. Fish. Serv., Northeast Fish. Sci. Cent. Ref. Doc. 13-21, 82 p. [Available from website.]

${ }^{3}$ NMFS (National Marine Fisheries Service). 2017. NOAA Fisheries announces at-sea monitoring coverage levels for groundfish sector fishery. [Available from Sustain. Fish. Div., Gt. Atl. Reg. Fish. Off., Natl. Mar. Fish. Serv., 55 Great Republic Dr., Gloucester, MA 01930.]

${ }^{4}$ NMFS (National Marine Fisheries Service). 2018. NOAA Fisheries announces reimbursement of sector at-sea monitoring costs. [Available from website, accessed September 2018.]
}

reimbursement, the negotiation of private contracts by multiple buyers (sectors) and multiple sellers (providers) indicates the potential for a competitive ASM services market. Furthermore, there are differences, such as those in landing ports and fishing trip durations, within and between groundfish sectors that affect the cost of placing monitors on vessels. In theory, competition between sectors in negotiating contracts would result in lower costs compared with costs of the more homogeneous contracts negotiated by the NMFS.

The transition from government-funded monitoring to industry-funded monitoring is not unique to the Northeast groundfish fishery. When catch shares were implemented in 2011 in the trawl fishery that targets groundfish off the Pacific coast of the United States, most monitoring costs were subsidized. This subsidy decreased over time, and the fishing industry in this region was fully responsible for monitoring costs starting in 2016 (PFMC and $\mathrm{NMFS}^{5}$ ). To our knowledge, however, no previous work has compared government and industry rates for providing observers in fisheries of the United States.

We tested the hypothesis that rates are lower for private contracts than for government contracts by calculating the actual costs incurred for the at-sea component of the ASM program under NMFS contracts (FY2013-2015) and comparing these costs to costs under privately negotiated contract terms during FY2016-2018. Using actual trips with an ASM observer during FY2013-2018, we applied the average costs under NMFS contracts and the private contract terms to directly compare costs under the 2 different contracting schemes. We tracked changes in aggregate atsea costs, as well as the distribution of these costs across trip type (single day versus multiple days), vessel type (large trawl, small trawl, or gill net), and landing region. We also estimated changes in the total cost of the ASM program under NMFS and sector contracts by including the costs of observer travel and at-sea observer training. Because we were unable to separate these costs to the trip level, we included them only in the aggregate. Finally, we looked at changes in fishing practices, specifically trip duration, used on ASM trips that may have resulted from cost-reduction incentives incorporated in the contracts negotiated by sectors.

\section{Materials and methods}

\section{Government-negotiated contracts}

The ASM program was fully funded by the NMFS from the start of FY2010 (May 2010) through February 2016. The NMFS contracted with 3 different service providers throughout this time period. At-sea monitoring contracts were renegotiated during FY2012-2013, changing

\footnotetext{
${ }^{5}$ PFMC (Pacific Fishery Management Council) and NMFS (National Marine Fisheries Service). 2017. West Coast groundfish trawl catch share program: five-year review, 487 p. PFMC, Costa Mesa, CA. [Available from website.]
} 
the ASM billing schedule from full to partial sea days and resulting in substantially lower costs. Under the full-sea-day billing schedule of FY2010-2011, the NMFS was charged on the basis of rounding the duration of an observer trip up to the nearest whole sea day (e.g., a 15-h trip would be billed as a 24-h trip). Under a schedule based on partial sea days, the NMFS was charged on the basis of rounding the duration of an observer trip up to the nearest quarter sea day (e.g., a 15-h trip would be billed as an 18-h trip). The net effect of this change was to decrease at-sea costs by $25 \%$.

To establish costs under the government contracts, we used billing information for FY2013-2015 from the Fisheries Sampling Branch of the NOAA Northeast Fisheries Science Center, allowing us to assign a cost per observed sea day (hereafter, we refer to observed sea days as sea days) for all aspects of the ASM program. A sea day is based on the billing schedule, with trip duration rounded up to quarter days $(6 \mathrm{~h})$ under the renegotiated NMFS contracts, such that a trip for which a vessel departed and landed on the same day and was at sea for $20 \mathrm{~h}$ would count as a full sea day (1.0 d). In terms of days absent, another margin we consider in our analysis, this same trip would simply be $0.83 \mathrm{~d}(20 \mathrm{~h} / 24 \mathrm{~h})$ absent. Days absent is calculated as the amount of time between when the vessel leaves the dock and when it lands, as filled out in the vessel trip report by the captain. The trip duration recorded by the captain and observer are not always identical but are generally close.

From September 2013 through December 2015, the average cost per sea day was $\$ 685$ (in 2017 U.S. dollars). The monthly data indicate limited variability with costs in a range of $\$ 653-729$ per sea day. The relative consistency in at-sea rates was largely based on the fact that the billing schedule (quarter sea days) did not change over the time period. The average cost for travel and lodging over the time period was $\$ 101$ per sea day. Training costs, associated with at-sea training, were $\$ 70$ per sea day. Adding the 3 components together, total ASM costs were $\$ 856$ per sea day (Table 1 ).

\section{Privately negotiated contracts}

Sectors that target groundfish negotiated contracts with service providers on an annual basis for FY2016-2018. Once a sector and provider reached an agreement, the sector sent the contract to the NOAA Greater Atlantic Regional Fisheries Office for approval. We used the approved contracts for all active groundfish sectors for each of the 3 fishing years. For FY2016-2017, 16 sectors had approved ASM contracts in place, and 14 sectors received approval for FY2018. Sectors contracted with 4 service providers in total in each year. Some sectors negotiated contracts that specified a universal daily rate per 24 -h period of service, and other sectors had contracts set up for charging on a prorated basis or for charging partial rates for the first and last days of a fishing trip. For some contracts, daily rates were different between single-day trips and multiday trips. The contracts also included observer travel costs in different ways. Some sectors were billed for travel costs only if the port of departure and return port were not among those listed in the contract or if the departure port and landing port were not the same. Other contracts stipulated that sectors would be charged only if observers had to travel a certain distance to board the departing vessel. Lastly, in contrast to the NMFS contracts, the costs associated with new observer training trips at sea were borne by the providers and incorporated into their charged costs per sea day.

We estimated the variable cost of ASM services for each sector as a function of the relevant component provisions contained within each contract. Broadly, variable costs for ASM services are the sum of the daily rates applied to monitored trips, any compensated travel costs, and, when applicable, lodging costs. Each component of these costs are uniquely specified in the contracts. Arithmetically, a

\section{Table 1}

Costs per sea day for at-sea monitoring (ASM) paid by the National Marine Fisheries Service (NMFS) for fishing years (FY) 2013-2015 of the groundfish fishery in the northeastern United States. Costs are given in 2017 U.S. dollars. Note that FY2013 included only the period September 2013-April 2014 and that FY2015 included only the period May 2015-December 2015. Costs for January and February 2016 were not factored into the calculations of costs per sea day for FY2015 because of subcontracting between ASM providers in these months.

\begin{tabular}{lcccccc}
\hline $\begin{array}{l}\text { Fishing } \\
\text { year }\end{array}$ & $\begin{array}{c}\text { No. of } \\
\text { ASM sea } \\
\text { days }\end{array}$ & $\begin{array}{c}\text { NMFS } \\
\text { cost }\end{array}$ & $\begin{array}{c}\text { At-sea } \\
\text { cost per } \\
\text { sea day }\end{array}$ & $\begin{array}{c}\text { Travel } \\
\text { cost per } \\
\text { sea day }\end{array}$ & $\begin{array}{c}\text { Training } \\
\text { cost per } \\
\text { sea day }\end{array}$ & $\begin{array}{c}\text { Total cost } \\
\text { per sea } \\
\text { day }\end{array}$ \\
\hline 2013 & 1557 & $\$ 1,084,591$ & $\$ 696$ & $\$ 108$ & $\$ 56$ & $\$ 859$ \\
2014 & 3327 & $\$ 2,271,070$ & $\$ 683$ & $\$ 93$ & $\$ 63$ & $\$ 833$ \\
2015 & 1192 & $\$ 805,558$ & $\$ 676$ & $\$ 111$ & $\$ 108$ & $\$ 894$ \\
Total & 6076 & $\$ 4,161,220$ & $\$ 685$ & $\$ 101$ & $\$ 70$ & $\$ 856$ \\
& & & & & &
\end{tabular}


full specification of the cost equation may be represented as follows:

$$
A S M_{\text {cost }}=\sum_{i=1}^{16} \sum_{t=1}^{n}\left[\begin{array}{l}
\left(\left(\alpha_{1} \beta_{1}\right)_{\mathrm{i}} D_{\text {first }}\right) \\
+\left(\left(\alpha_{2} \beta_{2}\right)_{\mathrm{i}} \sum D_{\text {whole }}\right) \\
+\left(\left(\alpha_{3} \beta_{3}\right)_{\mathrm{i}} D_{\text {last }}\right) \\
+\left(\left(\alpha_{4} \beta_{4}\right)_{\mathrm{i}} T\right)+\left(\left(\alpha_{5} \beta_{5}\right)_{\mathrm{i}} L\right)
\end{array}\right]
$$

where, for $i$ sectors and $t$ trips,

$A S M_{\text {cost }}=$ cost of ASM services;

$\alpha=$ a binary variable taking the value of 1 when a cost component applies and 0 when it does not;

$\beta=$ the applicable marginal rate for each billable service subcomponent;

$D=$ billable days absent (with partial first, last, and any intervening whole days treated uniquely);

$T=$ billable travel miles; and

$L=$ billable lodging days.

Ideally, total ASM costs under contracts negotiated by sectors would be estimated by using equation 1 ; however, we ran into 2 issues regarding travel and lodging costs. First, some sectors were charged for observer travel and lodging only when the observer traveled considerable distance to reach the vessel's port of departure. The observer travel distance is generally from their assigned home port to their port of departure and landing. Because we did not have access to observer travel distances, we were not able to determine the frequency with which travel and lodging charges were applicable for these sectors. Second, even for those sector trips for which we knew observer travel costs were incurred, on the basis of the ASM contract, we did not feel it was appropriate to estimate observer travel costs, such as lodging, and tolls, because we did not know where observers traveled from. We were, however, able to obtain the percentage of total ASM charges that were accrued to travel and lodging in FY2016 directly from the 4 ASM providers. Because the conditions for being charged for observer travel were generally unchanged between the 3 contract years for all providers, we assumed that travel as a percentage of costs remained the same in the contracts for FY2017 and FY2018. We estimated total ASM costs to the fishery by first calculating at-sea costs $\left(A t-s e a_{\text {cost }}\right)$ by using the following equation, which contains only the at-sea components of equation 1 . We then took the at-sea costs and added observer travel costs based on the information obtained from contract providers.

$$
A t-\text { sea }_{\text {cost }}=\sum_{i=1}^{16} \sum_{t=1}^{n}\left[\begin{array}{l}
\left(\left(\alpha_{1} \beta_{1}\right)_{\mathrm{i}} D_{\text {first }}\right) \\
+\left(\left(\alpha_{2} \beta_{2}\right)_{\mathrm{i}} \sum D_{\text {whole }}\right) \\
+\left(\left(\alpha_{3} \beta_{3}\right)_{\mathrm{i}} D_{\text {last }}\right)
\end{array}\right]
$$

\section{Comparisons of contracts}

To facilitate consistent comparison of ASM costs between the sector and NMFS contracts, records for all groundfish sector trips from September 2013 through August 2018 were retrieved from the Data Management and Imputation System maintained by the Greater Atlantic Regional Fisheries Office. Groundfish trip records were merged with a table of ASM trips from the Northeast Fisheries Science Center by using SAS Universal Viewer ${ }^{6} 1.4$ (SAS Institute Inc., Cary, NC), ensuring that only those trips that had an ASM observer on board were included. By linking each vessel with its sector affiliation, the data allowed exact matching of trips and contracted providers. When sectors negotiated ASM contracts for FY2016-2018, the membership of a sector may or may not have been the same as in previous years. A change in membership may have affected the negotiated contract terms. Sector affiliations for active vessels, however, did not change a great deal in our data set. Among the 366 active vessels, 300 (82\%) were active in only one sector throughout the 6-year comparison period.

Trip duration was calculated primarily by taking the difference between the observer recorded date and time of disembarking and of boarding the vessel. For a small number of observations, the observer did not record this information; in these cases, we used trip length recorded by the captain on the vessel trip report. Our data set contained 4072 trips with an ASM observer out of 34,956 groundfish trips made by sectors during the study period, yielding a composite ASM observer coverage rate of $11.65 \%$.

We calculated at-sea costs and total ASM costs by sea day and day absent. We then aggregated these costs by fishing year. For perspective on the relative magnitude of total ASM costs, we calculated ASM costs as a percentage of operating profit from sector groundfish trips. We defined operating profit as net revenue minus operating costs and sector fees. Operating costs were estimated by using a linear equation with cost information collected by observers in the ASM program and Northeast Fisheries Observer Program (NEFOP). The equation includes variability for monthly fuel prices, trip duration, number of crew members, vessel size, and gear type. Groundfish sector fees, used to cover administrative costs associated with running a sector, are collected from vessel landings or quota contributions. Sector fees were estimated as a flat fee of $\$ 0.035$ per pound of groundfish landed and $\$ 0.0075$ per pound of landed fish that were not groundfish on groundfish trips. (For more information on the estimation of operating costs, see Federal Register, 2019). All revenues and costs were adjusted to 2017 U.S. dollars by using the gross domestic product implicit price deflator (USBEA ${ }^{7}$ ).

\footnotetext{
${ }^{6}$ Mention of trade names or commercial companies is for identification purposes only and does not imply endorsement by the National Marine Fisheries Service, NOAA.

7 USBEA (U.S. Bureau of Economic Analysis). 2018. Gross domestic product: implicit price deflator [A191RI1Q225SBEA], retrieved from Federal Reserve Economic Data (FRED). Federal Reserve Bank of St. Louis, St. Louis, MO. [Available from website, accessed May 2018.]
} 
Additionally, we analyzed at-sea costs by trip type (single day and multiple days), vessel type (based on gear and length), and region of landing. Vessel types included small trawl vessels, with lengths of $0-18.3 \mathrm{~m}(0-60 \mathrm{ft})$; large trawl vessels, with lengths $\geq 18.3 \mathrm{~m}$, and gill-net vessels of all lengths (average length: $13.0 \mathrm{~m}$ for gillnet vessels and $18.8 \mathrm{~m}$ for trawl vessels). The regions for which data were analyzed included Massachusetts; Maine and New Hampshire; and Rhode Island, Connecticut, and mid-Atlantic states. Because we were unable to disaggregate observer travel costs, we did not compare total ASM costs at these margins. Furthermore, it is important to note that total ASM costs refer to only those costs defined in Table 1. Shoreside infrastructure costs of the ASM program, such as recruiting and training new observers, are covered by the NMFS; these costs were not included in our comparison.

Finally, we analyzed changes in fishing behavior, as measured by trip duration, on trips with an ASM observer between the period when contracts were negotiated by the NMFS (September 2013-February 2016) and the period covered by privately negotiated contracts (March 2016-August 2018). We did not include January and February 2016 when comparing trip duration. These months also were not included in our calculation of rates per sea day under NMFS contracts because subcontracting of providers during these 2 months affected rates. We measured changes in trip duration across vessel categories that were different than those used in our ASM cost comparison analysis. Rather than a combination of gear and vessel size, we chose to analyze changes in trip duration only by vessel size category. The following 4 size categories based on vessel length were used: $<13.7 \mathrm{~m}$ (<45 ft), 13.7-18.3 m (45-60 ft), 18.3-22.9 m (60-75 ft), and $\geq 22.9 \mathrm{~m}$ ( $\geq 75 \mathrm{ft}$ ). In our analysis, we specifically measured differences in days absent, the primary driver for the at-sea cost component of the ASM program. In doing so, we also compared trip length to lengths of trips with NEFOP observers. The purpose of this comparison was to determine if any apparent changes in aspects of ASM trips may have been driven by factors affecting all observed groundfish trips rather than by cost reductions from incentives embedded in the privately negotiated contracts.

\section{Results}

\section{Comparisons of at-sea and total costs}

Results from comparisons of at-sea and total costs by sea day and day absent across the 6-year period of FY20132018, for the entire fleet of groundfish vessels that operate in sectors are presented in Table 2. During the 3 years for which we examined data of sector contracts, at-sea costs were similar, ranging from $\$ 579$ to $\$ 602$ per observed sea day. At-sea costs per sea day were $\$ 83$ $(12.08 \%)$ to $\$ 106$ (15.41\%) lower under privately negotiated contracts than under NMFS contracts. Total costs per sea day were $\$ 233(27.21 \%)$ to $\$ 257$ (30.02\%) lower between private and government contracts, with travel costs based on data for FY2016 used for all 3 years. In many contracts, the sector was only responsible for covering travel costs if a vessel landed in a different port than the port at which the observer boarded or if the vessel landed in a port outside of the primary ports listed in the contract. For vessels operating in sectors under these contract specifications during FY2016, 30\% of (79 of 260) ASM trips resulted in the sector being charged for observer travel.

The ASM cost relative to total days absent, a measure of cost per total fishery effort from observed and unobserved trips, was $\sim \$ 80$ for private contracts at the aggregate coverage rate of $11.65 \%$ for the study period. This relative cost is distinguished from the cost per observed sea day or observed day absent, margins that are clearly less sensitive to overall coverage rates. No trend emerged from data for the 3 years of sector contracts that were analyzed (there was a slight increase in costs in FY2017 and a slight decrease in costs in FY2018); coverage rates were relatively similar during FY2016-2018. Given these findings, we hereafter present results for analysis of private contracts as the average of the 3 years of contract terms.

We next focused on a fishery-wide comparison of both at-sea costs and total costs aggregated over the 6-year period (Table 3). Sector contracts on average resulted in at-sea costs that were $\$ 0.83$ million (13.63\%) lower than costs under NMFS contracts and in total costs that were $\$ 2.17$ million $(28.45 \%)$ lower. At-sea cost reductions were consistent, ranging from $12.20 \%$ in FY2018 to $14.96 \%$ in FY2016. At-sea costs accounted for $80.02 \%$ of total costs under NMFS contracts and for $96.60 \%$ of total costs under private contracts over the course of the study period. Total costs were estimated to be $2.67 \%$ of operating profit generated from sector groundfish trips aggregated over the 6-year period, with a high of $4.57 \%$ in FY2014 and a low of $1.07 \%$ in FY2018 (Table 4). Year-to-year variation was driven largely by the ASM coverage rate. Total ASM costs were estimated to be $1.91 \%$ of operating profit under the averaged sector contracts, with a high of $3.28 \%$ in FY2014 and a low of $0.79 \%$ in FY2018. Operating profit was $75.47 \%$ of gross revenue over the course of the study period, with lower percentages in FY2013-2014.

A declining trend was evident both in ASM costs as a percentage of operating profit and in coverage rates during our 6-year study period (excluding the incomplete FY2013). Because our time series is limited, our analysis of the relationship between these 2 factors is not complete. As one would expect, higher ASM coverage resulted in greater payments to ASM providers under both NMFS and sector contracts. The number of ASM trips was also affected by the implementation of the extra-large-mesh (ELM) exemption that began in FY2016. This rule eliminated ASM coverage requirements for ELM trips fishing in portions of southern New England because of generally low amounts of groundfish caught on such trips (Federal Register, 2016). These exempted fishing trips were not counted as sector groundfish trips (the coverage rate denominator), inducing 


\section{Table 2}

At-sea and total costs in the Northeast groundfish fishery under contracts negotiated by the National Marine Fisheries Service (NMFS) and under privately negotiated contracts, applied to the period from September 2013 through August 2018. The NMFS negotiated contracts for fishing years (FY) 2013-2015, and fishery management representatives for groups of groundfish vessel owners, known as sectors, negotiated contracts for FY2016-2018. The number of observed sea days is based on the billing schedule for sea days paid by the NMFS (rounded up to quarter days). The number of observed days absent was calculated as the sum of trip durations recorded by captains on all observed trips. The number of total days absent was calculated as the sum of trip durations recorded by captains on all observed and unobserved trips. Costs are given in 2017 U.S. dollars. Note that the NMFS-negotiated at-sea cost per sea day (\$685) and total cost per sea day (\$856) are identical to those in Table 1. $n=$ number of days.

\begin{tabular}{llcc}
\hline Observed or total days & Contract & $\begin{array}{c}\text { Average } \\
\text { at-sea cost }\end{array}$ & $\begin{array}{c}\text { Average } \\
\text { total cost }\end{array}$ \\
\hline $\begin{array}{c}\text { Cost per observed sea day } \\
(n=8918)\end{array}$ & NMFS contracts & $\$ 685$ & $\$ 856$ \\
& FY16 contracts & $\$ 579$ & $\$ 599$ \\
& FY17 contracts & $\$ 602$ & $\$ 623$ \\
& FY18 contracts & $\$ 593$ & $\$ 615$ \\
& Average & $\$ 592$ & $\$ 612$ \\
Cost per observed day absent & NMFS contracts & $\$ 789$ & $\$ 986$ \\
$(n=7743)$ & FY16 contracts & $\$ 667$ & $\$ 690$ \\
& FY17 contracts & $\$ 694$ & $\$ 718$ \\
& FY18 contracts & $\$ 683$ & $\$ 709$ \\
& Average & $\$ 681$ & $\$ 705$ \\
Cost per day absent (observed & NMFS contracts & $\$ 92$ & $\$ 115$ \\
and unobserved: $n=66,626)$ & FY16 contracts & $\$ 78$ & $\$ 80$ \\
& FY17 contracts & $\$ 81$ & $\$ 83$ \\
& FY18 contracts & $\$ 79$ & $\$ 82$ \\
& Average & $\$ 79$ & $\$ 82$ \\
& & & \\
\hline
\end{tabular}

a significant decline in the number of sector groundfish trips for FY2016-18 relative to FY2013-2015. Had the ELM exemption been in place during FY2013-2015, many fewer trips would have been observed during that period. Revenue from the exempted trips, however, was included in annual gross revenue totals (Table 4) in order to maintain a consistent approach in the calculation of ASM costs relative to revenue.

\section{Disaggregated at-sea cost comparison}

The difference in at-sea costs between NMFS and sector contracts was heavily influenced by trip duration. On single-day trips, for which the sail and land dates are the same, costs associated with private contracts were comparable with those under NMFS contracts (Fig. 1). In fact, average at-sea costs on single-day trips were $\$ 26(6.23 \%)$ higher under sector contracts $(\$ 451)$ than under government contracts $(\$ 425)$. The regression line for the cost of private contracts (adjusted coefficient of determination [adj. $r^{2}$ ]=0.634) crosses the line for the cost of NMFS contracts at 3 different junctures, at trip durations of around 7, 15, and $24 \mathrm{~h}$. Costs under sector contracts generally exceeded costs under NMFS contracts for trips $<12 \mathrm{~h}$ in length. For trips with durations between 12 and $18 \mathrm{~h}$, costs were generally comparable. For trips $>18 \mathrm{~h}$ in length, costs were lower under contracts negotiated by sectors.

On multiday trips, for which sail and land dates differ, costs associated with sector contracts were lower, somewhat substantially, than costs under contracts negotiated by the NMFS (Fig. 2). The average cost for multiday trips was $\$ 613(18.01 \%)$ lower under private contracts $(\$ 2789)$ than under NMFS contracts (\$3402). The regression line for sector contracts on multiday trips (adj. $\left.r^{2}=0.976\right)$ fits the data well, providing a reliable estimate of the effect that trip duration has on costs. Annual changes in cost by trip type are shown in Figure 3.

Because trips with short and long durations yielded considerably different results, it follows that cost savings from sector contracts also varied when examined across vessel characteristics (Table 5). Operators of large trawlers ( $\geq 18.3 \mathrm{~m}$ in length), who primarily take multiday trips, achieved an $18.54 \%$ reduction in costs under private contracts. In contrast, minimal cost savings were associated with operation of small trawlers ( $<18.3 \mathrm{~m}$ in length) and 


\section{Table 3}

Estimated at-sea monitoring (ASM) costs (in millions of 2017 U.S. dollars) for all sector-enrolled vessels in the Northeast groundfish fishery for fishing years (FY) 2013-2018 under contracts negotiated by the National Marine Fisheries Service (NMFS) and under contracts negotiated by fishery management representatives for groups of groundfish vessel owners, known as sectors. Estimates of costs under sector contracts were calculated by applying the terms of 3 different contract years (FY2016, FY2017, and FY2018) to each ASM trip that occurred during FY20132018 and averaging the 3 values. Trips taken by sectors include only trips that were eligible to have an ASM observer. Note that FY2013 included only the period September 2013-April 2014 and that FY2018 included only the period May-August 2018.

\begin{tabular}{|c|c|c|c|c|c|c|c|}
\hline \multirow[b]{2}{*}{$\begin{array}{l}\text { Fishing } \\
\text { year }\end{array}$} & \multirow[b]{2}{*}{$\begin{array}{c}\text { No. of } \\
\text { sector } \\
\text { trips }\end{array}$} & \multirow[b]{2}{*}{$\begin{array}{l}\text { No. of } \\
\text { ASM } \\
\text { trips }\end{array}$} & \multirow[b]{2}{*}{$\begin{array}{c}\text { ASM } \\
\text { coverage } \\
\text { rate }\end{array}$} & \multicolumn{2}{|c|}{ At-sea cost } & \multicolumn{2}{|c|}{ Total cost } \\
\hline & & & & $\begin{array}{l}\text { NMFS } \\
\text { contracts }\end{array}$ & $\begin{array}{c}\text { Sector } \\
\text { contracts } \\
\quad \text { (avg. } \\
\text { FY16-18) }\end{array}$ & $\begin{array}{l}\text { NMFS } \\
\text { contracts }\end{array}$ & $\begin{array}{c}\text { Sector } \\
\text { contracts } \\
\quad(\text { avg. } \\
\text { FY16-18) }\end{array}$ \\
\hline 2013 & 5549 & 580 & $10.45 \%$ & $\$ 1.06$ & $\$ 0.90$ & $\$ 1.32$ & $\$ 0.93$ \\
\hline 2014 & 8972 & 1616 & $18.01 \%$ & $\$ 2.27$ & $\$ 1.97$ & $\$ 2.83$ & $\$ 2.03$ \\
\hline 2015 & 7640 & 972 & $12.72 \%$ & $\$ 1.29$ & $\$ 1.13$ & $\$ 1.61$ & $\$ 1.17$ \\
\hline 2016 & 5112 & 475 & $9.29 \%$ & $\$ 0.83$ & $\$ 0.71$ & $\$ 1.04$ & $\$ 0.73$ \\
\hline 2017 & 5304 & 315 & $5.94 \%$ & $\$ 0.51$ & $\$ 0.44$ & $\$ 0.64$ & $\$ 0.46$ \\
\hline 2018 & 2379 & 114 & $4.79 \%$ & $\$ 0.15$ & $\$ 0.13$ & $\$ 0.19$ & $\$ 0.14$ \\
\hline Total & 34,956 & 4072 & $11.65 \%$ & $\$ 6.11$ & $\$ 5.28$ & $\$ 7.63$ & $\$ 5.46$ \\
\hline
\end{tabular}

\section{Table 4}

Total estimated at-sea monitoring (ASM) costs as percentages of operating profits (in millions of 2017 U.S. dollars) for all sector-enrolled vessels in the Northeast groundfish fishery for fishing years (FY) 2013-2018 under contracts negotiated by the National Marine Fisheries Service (NMFS) and under contracts negotiated by groups of groundfish vessel owners, known as sectors. Fishery management representatives for sectors negotiated contracts for FY2016-2018. Estimates of costs under sector contracts were calculated by applying the terms of 3 different contract years (FY2016, FY2017, and FY2018) to each ASM trip that occurred during FY2013-2018 and averaging the 3 values. Note that FY2013 included only the period September 2013-April 2014 and that FY2018 included only the period May 2018-August 2018.

\begin{tabular}{|c|c|c|c|c|c|c|c|}
\hline \multirow[b]{2}{*}{$\begin{array}{l}\text { Fishing } \\
\text { year }\end{array}$} & \multirow[b]{2}{*}{$\begin{array}{c}\text { Gross } \\
\text { revenue }\end{array}$} & \multirow[b]{2}{*}{$\begin{array}{c}\text { Operating } \\
\text { profit }\end{array}$} & \multicolumn{2}{|c|}{ NMFS contracts } & \multicolumn{2}{|c|}{ Sector contracts } & \multirow[b]{2}{*}{$\begin{array}{c}\text { ASM } \\
\text { coverage } \\
\text { rate }\end{array}$} \\
\hline & & & $\begin{array}{c}\text { Total } \\
\text { cost }\end{array}$ & $\begin{array}{c}\text { Cost as } \\
\text { percentage } \\
\text { of operating } \\
\text { profit }\end{array}$ & $\begin{array}{c}\text { Total } \\
\text { cost }\end{array}$ & $\begin{array}{c}\text { Cost as } \\
\text { percentage } \\
\text { of operating } \\
\text { profit }\end{array}$ & \\
\hline 2013 & $\$ 55.92$ & $\$ 37.07$ & $\$ 1.32$ & $3.56 \%$ & $\$ 0.93$ & $2.51 \%$ & $10.45 \%$ \\
\hline 2014 & $\$ 85.86$ & $\$ 61.96$ & $\$ 2.83$ & $4.57 \%$ & $\$ 2.03$ & $3.28 \%$ & $18.01 \%$ \\
\hline 2015 & $\$ 76.39$ & $\$ 59.37$ & $\$ 1.61$ & $2.71 \%$ & $\$ 1.17$ & $1.97 \%$ & $12.72 \%$ \\
\hline 2016 & $\$ 72.11$ & $\$ 57.62$ & $\$ 1.04$ & $1.80 \%$ & $\$ 0.73$ & $1.27 \%$ & $9.29 \%$ \\
\hline 2017 & $\$ 65.57$ & $\$ 51.77$ & $\$ 0.64$ & $1.24 \%$ & $\$ 0.46$ & $0.89 \%$ & $5.94 \%$ \\
\hline 2018 & $\$ 22.43$ & $\$ 17.68$ & $\$ 0.19$ & $1.07 \%$ & $\$ 0.14$ & $0.79 \%$ & $4.79 \%$ \\
\hline Total & $\$ 378.29$ & $\$ 285.48$ & $\$ 7.63$ & $2.67 \%$ & $\$ 5.46$ & $1.91 \%$ & $11.65 \%$ \\
\hline
\end{tabular}

gillnetters, which are used primarily to take single-day trips. For regional landings, cost savings were more uniformly distributed. For all 3 regions, at-sea cost reductions of at least $10 \%$ were achieved with contracts negotiated by sectors. Because of a considerably higher volume of trips landing in Massachusetts than in the other 2 regions, absolute cost reductions for trips in Massachusetts greatly exceeded absolute cost reductions for trips landing in Maine and New Hampshire or in Rhode Island, Connecticut, and mid-Atlantic states. 


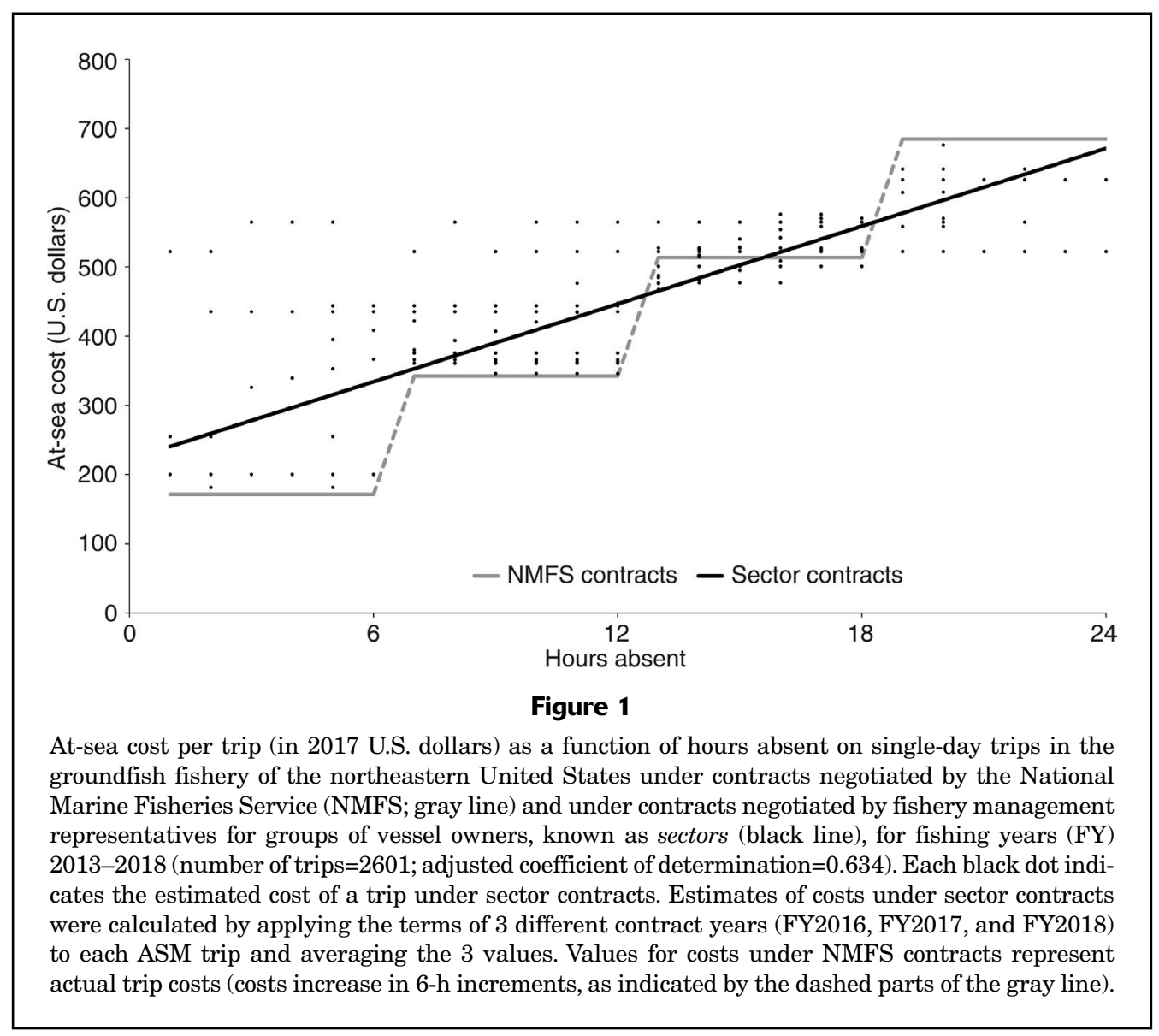

\section{Effects on trip duration}

Lastly, because our cost analysis was retrospective, we checked for changes in trip duration resulting from embedded incentives in sector contracts. In doing so, we chose to remove ASM trips made during FY2013-2015 that would have fallen under the ELM exemption had they been taken in FY2016-2018. We felt the removal of these trips was appropriate for making an accurate comparison between the 2 ASM contract periods of FY2013-2015 and FY20162018 because of ELM trips being considerably shorter than ASM trips. For example, ELM-exempt trips had average durations of $11 \mathrm{~h}$ over FY2016-2018 and ASM trips had average durations of $52 \mathrm{~h}$ over this time period. Private contracts do not appear to have had significantly incentivized changes in trip length when an ASM observer was on board (Table 6). Vessels in the smallest 2 categories, $<13.7 \mathrm{~m}$ and $13.7-18.3 \mathrm{~m}$, generally took single-day trips, and minimal changes in mean and median trip duration were observed for these vessels between the 2 contract periods. Vessels in the largest 2 size categories, 18.3$22.9 \mathrm{~m}$ and $\geq 22.9 \mathrm{~m}$, generally took multiday trips. The mean length of ASM trips taken by vessels in the largest 2 size categories was shorter during the private contract period than during the NMFS contract period. However, this decrease was not as sharp, in absolute or percentage terms, as the reduction in mean trip duration of trips with NEFOP observers between the 2 periods. The ASM trips made by vessels in the size category of $18.3-22.9 \mathrm{~m}$, in fact, experienced an increase in median trip length during the sector contract period compared with those during the NMFS contract period.

Over all vessel size categories, average ASM trip duration increased from $2.14 \mathrm{~d}$ under contracts negotiated by the NMFS to $2.28 \mathrm{~d}$ under contracts negotiated by sectors. Average length of trips with NEFOP observers decreased from $2.06 \mathrm{~d}$ to $1.81 \mathrm{~d}$ between contract periods. These results cannot be attributed to differences in coverage distribution for the 2 observer programs across vessel size categories. For both programs, coverage shifted away from the smallest vessels in the groundfish fishery (Table 6). During the NMFS contract period, $40 \%$ of (1078 of 2670) ASM trips and $46 \%$ of (867 of 1876) NEFOP trips were made on vessels $<13.7 \mathrm{~m}$. During the private contract period, these percentages dipped to $28 \%$ (289 of 1030 trips) and $35 \%$ (414 of 1185 trips), respectively. The share of ASM trips made by the largest vessels $(\geq 22.9 \mathrm{~m})$ increased by $8 \%$ (from $14 \%$ to $22 \%$ ) over the sector contract period, but an increase of only $1 \%$ (from $12 \%$ to $13 \%$ ) occurred for NEFOP trips over the same period. 


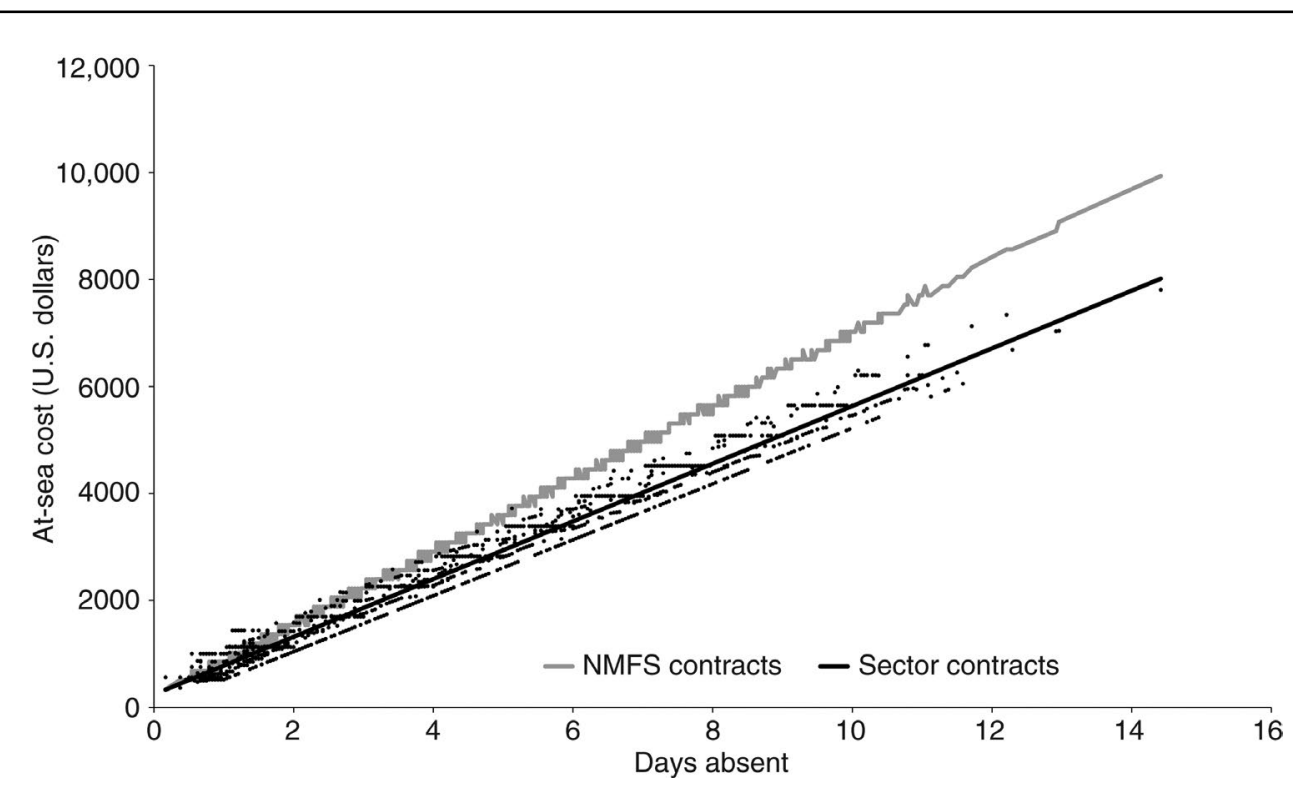

Figure 2

At-sea cost per trip (in 2017 U.S. dollars) as a function of days absent on multiday trips in the groundfish fishery of the northeastern United States under contracts negotiated by the National Marine Fisheries Service (NMFS; gray line) and under contracts negotiated by fishery management representatives for groups of vessel owners, known as sectors (black line), for fishing years (FY) 2013-2018 (number of trips=1471; adjusted coefficient of determination=0.976). Each black dot indicates the estimated cost of a trip under sector contracts. Estimates of costs under sector contracts were calculated by applying the terms of 3 different contract years (FY2016, FY2017, and FY2018) to each ASM trip and averaging the 3 values. Values for costs under NMFS contracts represent actual trip costs (costs increase in 6-h increments).

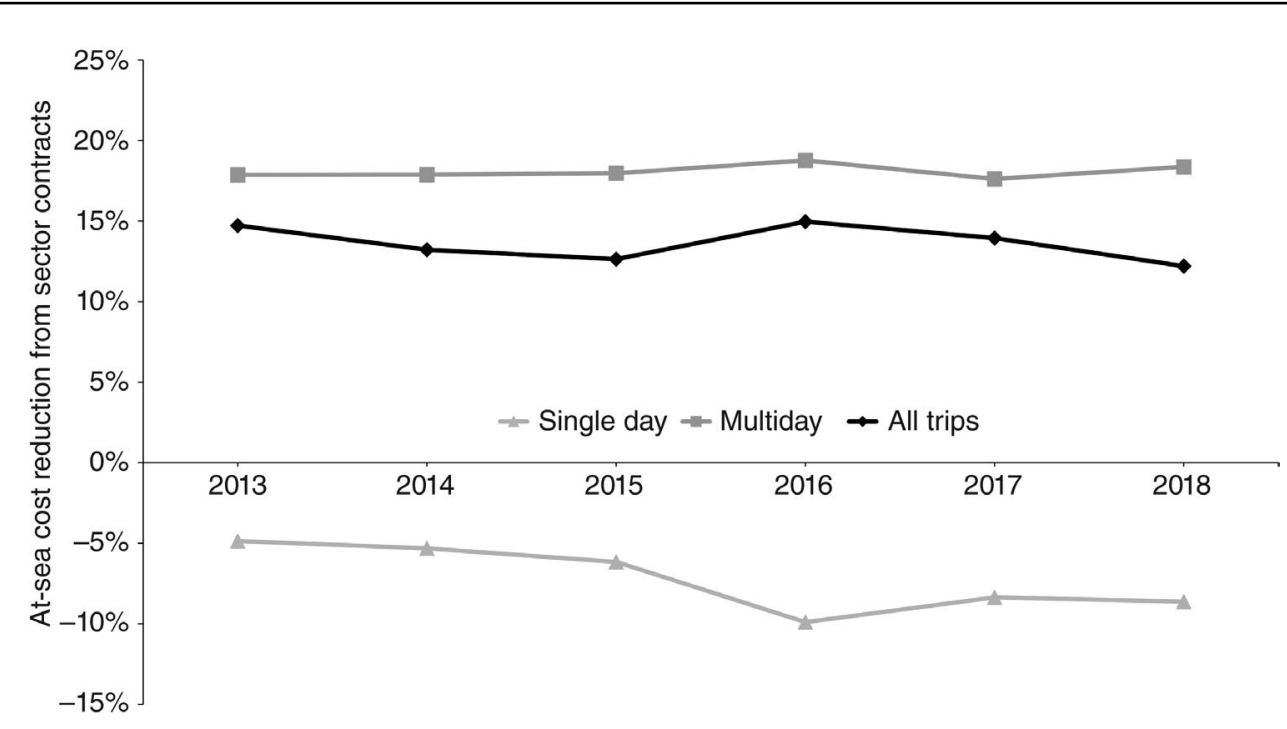

Figure 3

Estimated reductions in at-sea costs in the groundfish fishery of the northeastern United States under contracts negotiated by fishery management representatives for groups of groundfish vessel owners, known as sectors, compared with those under contracts negotiated by the National Marine Fisheries Service. Estimates are given for single-day (triangles), multiday (squares), and all (diamonds) trips during fishing years 2013-2018. 


\section{Table 5}

Trip type and at-sea cost (in millions of 2017 U.S. dollars) by vessel type and landing region for the sector portion of the Northeast groundfish fishery over fishing years (FY) 2013-2018 under contracts negotiated by the National Marine Fisheries Service (NMFS) and under privately negotiated contracts. Fishery management representatives for groups of groundfish vessel owners, known as sectors, negotiated the private contracts. Estimates of costs under sector contracts were calculated by applying the terms of 3 different contract years (FY2016, FY2017, and FY2018) to each ASM trip that occurred during FY2013-2018 and averaging the 3 values. Vessel types include large trawlers $\geq 18.3 \mathrm{~m}$ ( $\geq 60 \mathrm{ft}$ ) in length, small trawlers $<18.3 \mathrm{~m}$ in length, and gillnetters of all lengths (average length for gillnetters was $13.0 \mathrm{~m}$ ). The landing regions include Connecticut $(\mathrm{CT})$, Rhode Island (RI), and mid-Atlantic states (mid-Atl.), Massachusetts (MA), and Maine (ME) and New Hampshire (NH).

\begin{tabular}{lcccccc}
\hline & \multicolumn{2}{c}{ No. of trips } & & \multicolumn{2}{c}{ At-sea cost } & \\
\cline { 2 - 3 } Category & $\begin{array}{c}\text { Single } \\
\text { day }\end{array}$ & Multiday & $\begin{array}{c}\text { Percentage } \\
\text { of Multiday } \\
\text { trips }\end{array}$ & $\begin{array}{c}\text { Sector } \\
\text { contracts }\end{array}$ & $\begin{array}{c}\text { NMFS } \\
\text { contracts }\end{array}$ & $\begin{array}{c}\text { Cost reduction } \\
\text { under sector } \\
\text { contracts }\end{array}$ \\
\hline Vessel type & & & & & & \\
$\quad$ Gillnetter & 1453 & 209 & $12.58 \%$ & $\$ 1.09$ & $\$ 1.12$ & $2.79 \%$ \\
$\quad$ Large trawlers & 249 & 1000 & $80.06 \%$ & $\$ 3.44$ & $\$ 4.23$ & $18.54 \%$ \\
$\quad$ Small trawlers & 945 & 116 & $10.93 \%$ & $\$ 0.65$ & $\$ 0.65$ & $0.97 \%$ \\
Region & & & & & & \\
CT/RI/mid-Atl. & 507 & 119 & $19.01 \%$ & $\$ 0.43$ & $\$ 0.49$ & $11.74 \%$ \\
MA & 1679 & 998 & $37.28 \%$ & $\$ 4.09$ & $\$ 4.78$ & $14.45 \%$ \\
ME/NH & 542 & 227 & $29.52 \%$ & $\$ 0.76$ & $\$ 0.84$ & $10.02 \%$ \\
\hline
\end{tabular}

\section{Discussion}

The ASM costs in the Northeast groundfish fishery were lower under private contracts than under those negotiated by the NMFS during our comparison period of September 2013-August 2018. We estimated that average at-sea costs were $14 \%$ lower over this period when applying contract terms negotiated by sectors (for FY2016-2018) than when applying average costs under NMFS contracts (for September 2013-December 2015). Aggregate reductions in costs for the at-sea component of the ASM program were driven by sectors composed primarily of vessels that took multiday trips, generally large trawlers. We found that at-sea rates for single-day trips were slightly higher under sector contracts than under NMFS contracts. Providers are likely to have lower marginal per-observed-day costs on multiday trips, perhaps because of lower associated administrative and transportation costs. Alternatively, higher costs for single-day trips under sector contracts may reflect a broad shift in fishery effort toward large vessels $(\geq 22.9 \mathrm{~m})$ (Murphy et al. ${ }^{1}$ ) and optimization of contracts by providers to cover sectors that contain large vessels. In either case, our hypothesis of lower costs under private contracts was realized, although the role of vessel heterogeneity within and between sectors did not appear to be a major factor in these cost reductions. That is, uniformly, sectors were able to negotiate lower rates than those under NMFS contracts for multiday trips but not for single-day trips.

On the demand side, the implementation of the ELM exemption (Federal Register, 2016), which started in FY2016 and continued in FY2017-2018, effectively lengthened ASM trips. Trips under ELM exemption were substantially shorter $(36 \mathrm{~h})$ on average than other groundfish trips that were eligible to be selected to carry an ASM observer over the course of FY2016-2018. This exemption alone likely accounted for a shift toward observer coverage on multiday trips during the sector-funded ASM period: $69 \%$ of trips covered by an ASM observer during FY2013-2015 were single-day trips. This percentage fell to $62 \%$ of trips during FY2016-2018. Other changing conditions in the fishery, such as quota allocations and quota prices, may have also contributed to this shift toward multiday trips. In any case, if sectors were aware that fewer short duration trips would be covered, they may have placed a greater focus on costs for multiday trips in contract negotiations. If the shift to sector negotiation of ASM had occurred in FY2012, as originally stipulated (Federal Register, 2010), the at-sea rates under private contracts may have looked quite different because of a higher proportion of coverage on single-day trips than on multiday trips.

When observer travel and training costs were included, the savings under private contracts were significantly larger $(28 \%)$. We were unable to analyze effects of distribution for total ASM costs because we had only aggregated provider-level information on observer travel costs. Because observer travel was a small cost component, and observer training was not a separable cost to any sector, total ASM costs would have been only slightly higher than at-sea costs for any particular segment of the sector 


\section{Table 6}

Duration of trips, in days and by vessel size, in the sector portion of the Northeast groundfish fishery that were observed through the at-sea monitoring (ASM) program and the Northeast Fisheries Observer Program (NEFOP). The ASM program operated under contracts negotiated by the National Marine Fisheries Service (NMFS) from September 2013 through February 2016 and under contracts negotiated by fishery management representatives for groups of groundfish vessel owners, known as sectors, from March 2016 through August 2018. Vessel size categories are based on length: $<13.7 \mathrm{~m}(<45 \mathrm{ft}), 13.7-18.3 \mathrm{~m}(45-60 \mathrm{ft}), 18.3-22.9 \mathrm{~m}(60-75 \mathrm{ft})$, and $\geq 22.9 \mathrm{~m}(\geq 75 \mathrm{ft})$. The numbers of ASM and NEFOP trips $(n)$ are given separately for trips that occurred during the period of NMFS-negotiated ASM contracts and for trips that occurred during the period of sectornegotiated ASM contracts. SD=standard deviation.

\begin{tabular}{|c|c|c|}
\hline \multirow[b]{2}{*}{ Vessel size } & \multicolumn{2}{|c|}{ ASM contract period } \\
\hline & NMFS & Sector \\
\hline \multicolumn{3}{|c|}{ Vessels $<13.7 \mathrm{~m}$} \\
\hline \multicolumn{3}{|c|}{ ASM trips (NMFS: $n=1078$; sector: $n=289$ ) } \\
\hline Mean & 0.75 & 0.69 \\
\hline Median & 0.50 & 0.50 \\
\hline SD & 0.96 & 0.95 \\
\hline \multicolumn{3}{|c|}{ NEFOP trips (NMFS: $n=867 ;$ sector: $n=414$ ) } \\
\hline Mean & 0.80 & 0.76 \\
\hline Median & 0.54 & 0.50 \\
\hline $\mathrm{SD}$ & 0.90 & 1.03 \\
\hline \multicolumn{3}{|c|}{ Vessels $13.7-18.3 \mathrm{~m}$} \\
\hline \multicolumn{3}{|c|}{ ASM trips (NMFS: $n=725$; sector: $n=315$ ) } \\
\hline Mean & 0.93 & 0.83 \\
\hline Median & 0.63 & 0.54 \\
\hline $\mathrm{SD}$ & 1.10 & 1.01 \\
\hline \multicolumn{3}{|c|}{ NEFOP trips (NMFS: $n=482$; sector: $n=395$ ) } \\
\hline Mean & 1.10 & 0.86 \\
\hline Median & 0.60 & 0.58 \\
\hline $\mathrm{SD}$ & 1.29 & 1.03 \\
\hline \multicolumn{3}{|c|}{ Vessels $18.3-22.9 \mathrm{~m}$} \\
\hline \multicolumn{3}{|c|}{ ASM trips (NMFS: $n=481$; sector: $n=196$ ) } \\
\hline Mean & 3.49 & 3.04 \\
\hline Median & 2.42 & 2.73 \\
\hline $\mathrm{SD}$ & 3.05 & 2.51 \\
\hline \multicolumn{3}{|c|}{ NEFOP trips (NMFS: $n=302 ;$ sector: $n=221$ ) } \\
\hline Mean & 4.03 & 3.07 \\
\hline Median & 3.52 & 1.96 \\
\hline SD & 3.13 & 2.83 \\
\hline \multicolumn{3}{|c|}{ Vessels $\geq 22.9 \mathrm{~m}$} \\
\hline \multicolumn{3}{|c|}{ ASM trips (NMFS: $n=386$; sector: $n=230$ ) } \\
\hline Mean & 6.65 & 5.61 \\
\hline Median & 6.94 & 5.46 \\
\hline SD & 2.65 & 2.54 \\
\hline \multicolumn{3}{|c|}{ NEFOP trips (NMFS: $n=225$; sector: $n=155$ ) } \\
\hline Mean & 6.37 & 5.26 \\
\hline Median & 6.58 & 5.17 \\
\hline SD & 2.76 & 2.53 \\
\hline
\end{tabular}

portion of the groundfish fishery. Under NMFS contracts, observer travel and training imposed much higher costs than under private contracts. Therefore, for owners of small trawl and gill-net vessels, who experienced minimal at-sea cost reductions from sector contracts, reductions in total ASM costs were likely more substantial than at-sea cost reductions.

It is important to note that we assigned at-sea costs on a trip basis in our analysis. In actuality, no regulatory restriction currently exists on how sectors secure 
payment to ASM providers. Sectors may bill vessels individually for each ASM trip or estimate their aggregate ASM costs and apportion them across their membership in some other envy-free manner. The method of assigning costs is an important consideration. A payment mechanism such as the one we assumed in our study may provide an incentive for vessel operators to cut short trips with an ASM observer, although we did not find evidence of such a behavioral change following the transition to sector negotiation of ASM contracts when we compared ASM trips with NEFOP trips. Importantly, federal reimbursement of sector costs may have muted any such incentive. Intra-sector cost incidence is a critical component of the shift from government to private contracts, and one for which we currently have no data to examine.

Although sector negotiation of contracts appears to have reduced the cost of ASM services, the transition may have induced other effects to the monitoring program, either directly or indirectly, that are beyond the scope of our study. To the extent that ASM is a cost to sectors and their members, the shift to private contracts may create consistent pressure on fishery managers to reduce observer coverage. As evidence of this pressure, changes were made to the calculation of the total (ASM and NEFOP trips combined) target rate of observer coverage for the groundfish fishery in FY2016 (Federal Register, 2016), and the target rate was lowered from a range of 22-26\% for FY2012-2015 to 14\% for FY2016. The target rates for FY2017 and FY2018 were slightly higher (16\% and 15\%, respectively; $\mathrm{NMFS}^{8}$ ). Under lower observer coverage, concerns over data reliability may increase. For example, a decrease in precision of discard estimates occurred during FY2016-FY2018 from the level of precision found during FY2013-FY2015 (GARFO ${ }^{9}$ ). Evidence of changes in fishing behavior when an observer is on board, observer bias, has also been reported (NEFMC, 2019). Additionally, if compensation to the ASM observers themselves was to decline under sector contracts, employee turnover may increase and the quality of recruited monitors may decrease. Higher turnover would not only result in relatively higher observer training costs but also decrease the quality of the data collected by observers. In essence, the shift to privately negotiated contracts for ASM services presents a principal-agent problem, the effects of which are not yet well understood.

The long-term applicability of our findings to other fisheries in the United States is uncertain. In the future, other fisheries may follow the Northeast groundfish

\footnotetext{
${ }^{8}$ NMFS (National Marine Fisheries Service). 2017. NOAA Fisheries announces reimbursement rate of 60 percent for at-sea monitors in 2017. [Available from Sustain. Fish. Div., Gt. Atl. Reg. Fish. Off., Natl. Mar. Fish. Serv., 55 Great Republic Dr., Gloucester, MA 01930.]

${ }^{9}$ GARFO (Greater Atlantic Regional Fisheries Office). 2020. Summary of analyses conducted to determine at-sea monitoring requirements for multispecies sectors FY2020, 12 p. GARFO, Gloucester, MA. [Available from website.]
}

fishery in implementing additional monitoring requirements and in transitioning from government to industry payment to cover these additional costs. The trawl fishery that targets groundfish off the Pacific coast of the United States followed this general path upon implementation of individual fishing quotas, although individual vessel owners in this trawl fishery do not have the same ability to negotiate costs per sea day as sectors in the Northeast groundfish fishery $\left(\right.$ Edick $^{10}$; Westly ${ }^{11}$ ). Our results may be applicable to the partial-observer-coverage fisheries in Alaska, some of which operate under catch shares (for a complete list of partial-coverage fisheries in Alaska, see AFSC and $\mathrm{ARO}^{12}$ ). These fisheries currently have landings fees in place to pay for observer coverage. The NMFS collects and administers the fees, which are used to pay contracting costs with a third-party provider of observers. A co-op model may potentially decrease observer costs by allowing fishing fleets to contract directly with observer providers, as is currently done in the full-observer-coverage co-op fisheries in Alaska (Figus $^{13}$ ).

Given the possibility of electronic monitoring having an increasing role in at-sea coverage in U.S. fisheries, including in the Northeast groundfish fishery, it is important to mention that this technology was not part of our cost comparison. Given the large upfront cost associated with electronic monitoring (Cap Log Group ${ }^{14}$ ), a cost comparison of government and industry payment of electronic monitoring services would look quite different than the comparison we present here.

\section{Acknowledgments}

The authors would like to thank M. Grant of the Greater Atlantic Regional Fisheries Office, who was instrumental in providing information necessary for this paper. This work would not have been possible without the collective efforts of the Fisheries Sampling Branch of the Northeast Fisheries Science Center and all the men and women who go to sea as observers and at-sea monitors. We are also very grateful for the providers of at-sea monitoring for answering our inquiries.

$\overline{10}$ Edick, D. 2019. Personal commun. Alaskan Observers, 130 Nickerson St., Unit 206, Seattle, WA 98109.

11 Westly, E. 2019. Personal commun. Saltwater Inc., 733 N St., Anchorage, AK 99501.

12 AFSC (Alaska Fisheries Science Center) and ARO (Alaska Regional Office). 2019. North Pacific Observer Program 2018 annual report. NOAA, Natl. Mar. Fish. Serv., Alaska Fish. Sci. Cent., AFSC Processed Rep. 2019-04, 148 p. [Available from website.]

${ }^{13}$ Figus, E. 2019. Personal commun. North Pacific Fishery Management Council, 1007 W. 3rd Ave., Ste. 400, Anchorage, AK 99501.

14 Cap Log Group. 2019. Projected cost of providing electronic monitoring to 100 vessels in New England's groundfish fishery, 20 p. Report commissioned by the Nature Conservancy. [Available from website.] 


\section{Literature cited}

\section{Federal Register.}

2010. Magnuson-Stevens Fishery Conservation and Management Act provisions; fisheries of the northeastern United States; Northeast (NE) multispecies fishery; amendment 16. Fed. Regist. 75:18262-18353. [Available from website.] 2016. Magnuson-Stevens Fishery Conservation and Management Act provisions; fisheries of the northeastern United States; Northeast multispecies fishery; framework adjustment 55. Fed. Regist. 81:26412-26452. [Available from website.]
2019. Magnuson-Stevens Fishery Conservation and Management Act provisions; fisheries of the northeastern United States; Northeast multispecies fishery; framework adjustment 58. Fed Regist. 84:34799-34815. [Available from website.]

NEFMC (New England Fishery Management Council).

2019. Scientific and statistical committee sub-panel peer review report for the groundfish plan: development team analyses of groundfish monitoring, 19 p. NEFMC, Newburyport, MA. [Available from website.] 